\title{
The Effect of Ultraviolet-B Radiation Exposure on Hibiscus cannabinus Linn with its Phytochemical and Pharmacological Responses
}

\author{
T Sundarrajan ${ }^{1, *}$, V Velmurugan', MK Kathiravan'2, K Manikandan ${ }^{3}$, KS Lakshmi ${ }^{3}$, MR Ganesh $^{4}$
}

T Sundarrajan ${ }^{1, *}$, V Velmurugan ${ }^{1}$, MK Kathiravan², K Manikandan³, KS Lakshmi ${ }^{3}$, MR Ganesh ${ }^{4}$

'Department of Pharmaceutical Chemistry SRM College of Pharmacy, SRMIST, Kattankulathur, Tamil Nadu, INDIA. 2209, Dr. APJ Abdul Kalam Research Lab SRM College of Pharmacy, SRMIST, Kattankulathur, Tamil Nadu, INDIA. ${ }^{3}$ Department of Pharmaceutical Analysis, SRM College of Pharmacy, SRMIST, Kattankulathur, Tamil Nadu, INDIA. ${ }^{4}$ IIISM, SRM IST, Kattankulathur, Tamil Nadu, INDIA.

\section{Correspondence}

Dr. T. Sundarrajan M.Pharm., Ph,D Associate Professor, Department of Pharmaceutical Chemistry, SRM College of Pharmacy, SRMIST, Kattankulathur, Tamilnadu, INDIA.

E-mail: chemistrysundar@gmail.com History

- Submission Date: 28-06-2019;

- Review completed: 14-08-2019;

- Accepted Date: 14-08-2019.

DOI : 10.5530/pj.2019.11.235

Article Available online http://www.phcogj.com/v11/i6s

\section{Copyright}

(C) 2019 Phcogj.Com. This is an openaccess article distributed under the terms of the Creative Commons Attribution 4.0 International license.

\begin{abstract}
Aim: Exposure of UV-B Radiation onHibiscus cannabinus Linn and to evaluate both Phytochemical and Pharmacological responses. Objective: UV-B can increase the nutrients contents from plants, plants become tastier and increases the yield and UV-will make plants resistant to fungal infections and stimulate the production of phytomarkers. Material and Methods: Hibiscus cannabinus Linn seeds were soaked with $50 \% \mathrm{H}_{2} \mathrm{O}_{2}$ for 12 hours and then inoculated with the Azospirillum. UV-B radiation cabinet was provided by UV lamps which are above $15 \mathrm{~cm}$ from control maintained. Normal daylight exposed control group Seedlings irradiated for 2 hour per day (12.30 pm to $2.30 \mathrm{pm})$ for 20 days. Results and Discussion: 20 days treatment increases total phenolic contents and sugars content were decreased in uncovered leaf tissue. Protein content was at first diminished but expanded on the 20 day of UV-B treatment. Also, perform pharmacological studies no toxic elements are observed 20 days treatment and pharmacological activity by using anticancer activity by using human colon HT-29 cancer cell line. UV light exposed plants shows good anticancer activity when compared with non UV exposed Plant.

Key words: Hibiscus cannabinus Linn, UV-B radiation, Cancer cells line HT-29, Total phenolic contents.
\end{abstract}

\section{INTRODUCTION}

An ultraviolet ray is that incorporate the electromagnetic spectrum they are generally found inside the 400 and 10-nanometer wavelength. The Earth's is shielded from short-wave UV by an ozone layer in the stratosphere. Around 95 percent of this UV radiation is consumed by the Ozone layer. ${ }^{1}$ UV can expand the nutrients from plants, therefore, plants will be more delectable. UV-will makes plants progressively impervious to contagious contaminations. Ultra-violet light are amazingly hurtful to these microbes and more often than not prompt their demise. In spite of the fact that it can slaughter off unsafe microorganisms, it likewise impacts the helpful ones, subsequently annihilating any common connection between the plants and the microbes. ${ }^{2}$

Damage of the stratospheric ozone layer the level of ultraviolet radiation reaching the biosphere, especially in the range of UV-B $(280-320 \mathrm{~nm})$ react with oxygen to convert ozone its compound protective mechanism of ozone layer. ${ }^{3-5}$

The limitation of herbal plant research less yield, diseases state of plants and using fertiliser produces the toxic effect of plants as well as human so new techniques are used to increases the yield of medicinal plants, reduced fertiliser usage and increases biomarkers. ${ }^{6}$

\section{MATERIALS AND METHODS}

\section{Collection of plant sample}

Hibiscus cannabinus Linn seeds were collected from Kaviya Garden Chennai. Surface-sterilised seeds were first soaked in $\mathrm{H}_{2} \mathrm{O}_{2}$ for 12 hours and then inoculated with the Azospirillum. Hydrogen peroxide concentrations of $50 \%$ were prepared with distilled water and then replaced to garden soil in trays, containing red earth, sand and farmyard manure in (1:2:1). UV-B radiation cabinet was provided by UV lamps which are above $15 \mathrm{~cm}$ from control maintained. Normal daylight exposed to control group. Seedlings irradiated for 1 hour per day $(12.30 \mathrm{pm}$ to $1.30 \mathrm{pm})$ for 20 days (Figures 1 and 2).

\section{Chemicals}

Analytical grade 3-(4,5-dimethylthiazol-2yl)-2,5-diphenyltetrazolium bromide (MTT), dimethylsulfoxide (DMSO), doxorubicin and other chemicals purchased from Himedia Laboratories private limited, Mumbai, Reagent D, Reagent E, Folin-Ciocalteu Phenol reagent.

\section{Estimation of biochemical constituents}

\section{Estimation of protein}

Protein content determined by Lowry et al. method. $0.5 \mathrm{gm}$ of plants was smashed with $80 \%$ Acetone. This

Cite this article: Sundarrajan T, Velmurugan V, Kathiravan MK, Manikandan K, Lakshmi KS, Ganesh MR. The Effect of Ultraviolet-B Radiation Exposure on Hibiscus cannabinus Linn with its Phytochemical and Pharmacological Responses. Pharmacog J. 2019;11(6)Suppl:1540-3. 


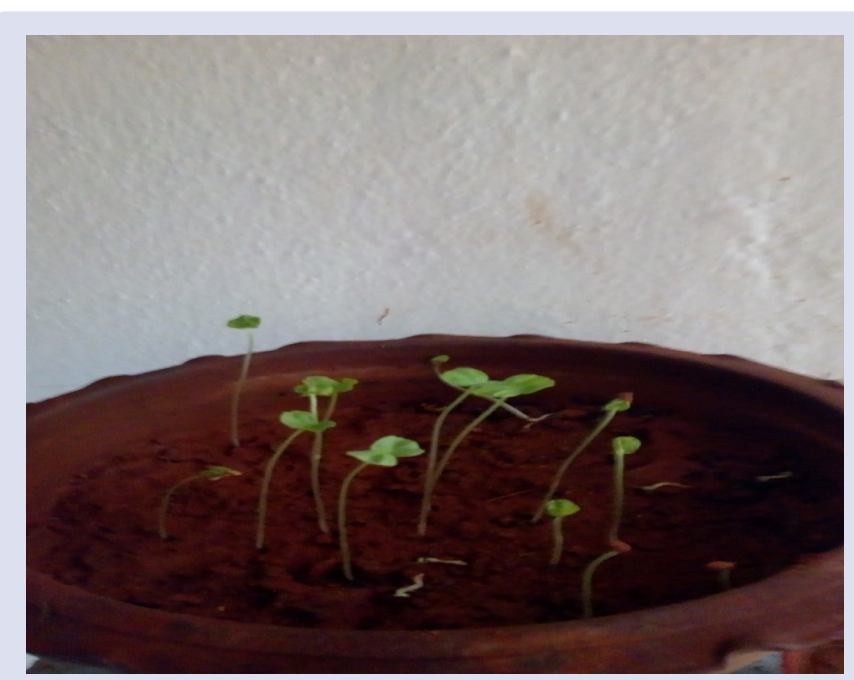

Figure 1: Effect of UV-B radiation for 20 days exposed Hibiscus cannabinus Linn.

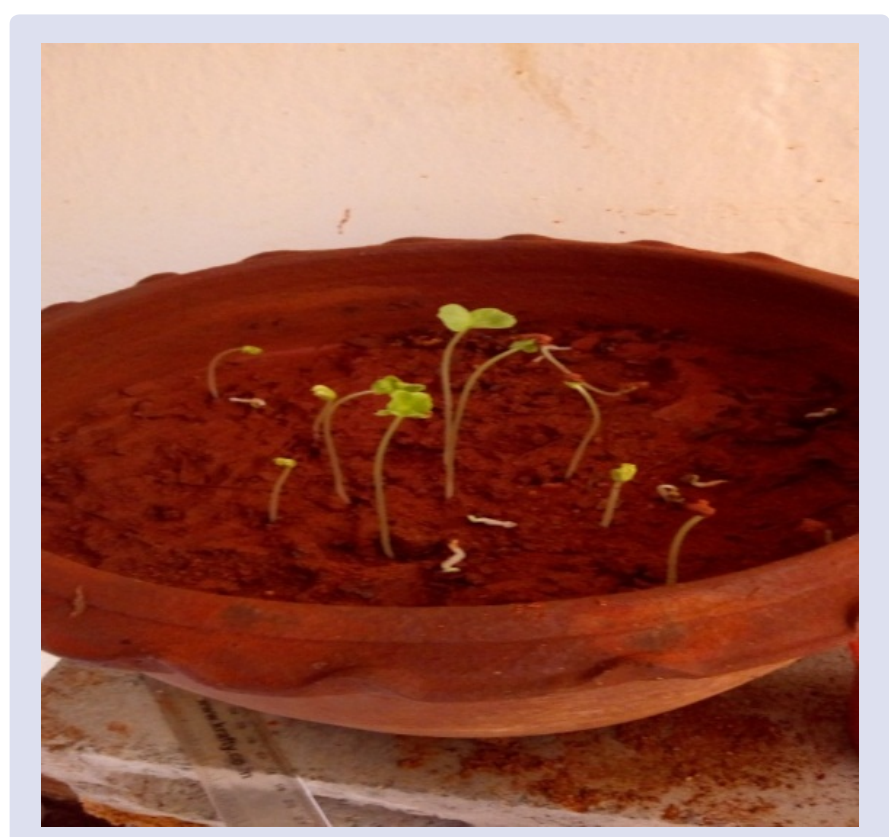

Figure 2: Effect of Non-UV-B radiation 20 days exposed Hibiscus cannabinus Linn.

extract used as a sample. $0.3 \mathrm{ml}$ of extract diluted to $1 \mathrm{ml}$. Then added $2 \mathrm{ml}$ of Reagent $\mathrm{D}$ and kept in for 10 minutes at room temperature. 0.6 $\mathrm{Ml}$ of Reagent $\mathrm{E}$ added and placed in 20 minutes at room temperature. Optical density was read at $660 \mathrm{~nm}$ with bovine serum albumin as a standard. ${ }^{7.8}$

\section{Estimation of chlorophylls}

Two gram of leaf was finely cut and gently mixed with a clean mortar and pestle. To this add $20 \mathrm{ml}$ of $80 \%$ acetone and $0.5 \mathrm{gm} \mathrm{MgCO}_{3}$. The materials were further grinded gently. The sample was then put into a refrigerator at $40 \mathrm{C}$ for 5 hours. Thereafter, the sample was centrifuged at $500 \mathrm{rpm}$ for 5 minutes. The supernatant was transferred to $100 \mathrm{ml}$ volumetric flak. The final volume was made up to $100 \mathrm{ml}$ with addition of $80 \%$ acetone. The color absorbance of the solution was estimated by a spectrophotometer using 645 and $663 \mathrm{~nm}$ wavelength against the solvent. Acetone (80\%) was used as a blank. ${ }^{9,10}$

\section{Estimation of total sugars}

Total sugars estimated by a phenol-sulphuric acid method. $0.5 \mathrm{gm}$ of plants smashed with $80 \%$ Acetone. This extract was used as a sample.0.3 $\mathrm{ml}$ of extract was diluted to $1 \mathrm{ml}$ and to that $0.5 \mathrm{ml}$ of $80 \%$ phenol, $4 \mathrm{ml}$ of con. $\mathrm{H}_{2} \mathrm{O}_{4}$ added and absorbance read at $490 \mathrm{~nm}$. Concentration of total sugars was determined using glucose as standard. ${ }^{11}$

\section{Estimation of total phenolic content}

The total phenol content was determined spectrophotometrically using the Folin-Ciocalteu method. Singleton and Rossi (1967) is oxidation / reduction method for phenolic compounds. $0.2 \mathrm{ml}$ of the sample diluted to $1 \mathrm{ml} .0 .7 \mathrm{ml}$ of Folin-Ciocalteu reagent was added to it and incubated 5 minutes at $220^{\circ} \mathrm{C}$. Then $1 \mathrm{ml}$ of $\mathrm{Na}_{2} \mathrm{CO}_{3}$ was added and again kept at $220^{\circ} \mathrm{C}$ for 90 minutes. The absorbance was measured at $725 \mathrm{~nm} .^{12}$

\section{Estimation of total proline content}

Proline contents determined by Plants treated with sulphosalicylic acid. The extract was used for estimating proline contents with help of spectrophotometric analysis. ${ }^{13}$

Anticancer activity against human colon (HT-29) cancer cell line

\section{Cell culture}

Colorectal cancer cell lines HT-29 collected from Texas Southern University. Cultured Cells by using RPMI 1640 medium add $10 \%$ FBS with antibiotics. Cells were kept at $37^{\circ} \mathrm{C}$ in a well humidified condition of $5 \%$ carbon dioxide in $95 \%$ sterilized air. HT-29 cells were added with $100 \mathrm{nM}$ of phorbol myristate acetate for 72 hours to induce differentiation into macrophages. After differentiation, non-reacted cells were separated by aspiration and adherent macrophages were washed with RPMI 1640 medium 3 times and then kept in cell culture medium at $37^{\circ} \mathrm{C} .^{14}$

\section{Cell viability}

The effect of plants extract of both UV and non UV treated plants extract on cell proliferation in HT-29 cells was determine by using Cell viability 96 well plate assay. The viable cells seeded at a thickness of $5 \times 104(100 \mu /$ well $)$ in 96-well plates and brooded in a humidified environment to frame a cell monolayer. After $24 \mathrm{hr}$, the supernatant

Table 1: Effect of UV radiation and Non-UV radiation on phytochemical parameters.

\begin{tabular}{cccc}
\hline S.No & $\begin{array}{c}\text { Phytochemical } \\
\text { Parameters }\end{array}$ & $\begin{array}{c}\text { Non-UV-B } \\
\text { Treatment }\end{array}$ & UV Treatment \\
\hline 1 & Total chlorophylls & $2.834 \pm 0.0025$ & $0.383 \pm 0.0025$ \\
2 & Carotenoid & $0.273 \pm 0.0034$ & $0.193 \pm 0.0024$ \\
3 & Protein & $0.816 \pm 0.160$ & $0.65 \pm 0.001$ \\
4 & Proline & $0.588 \pm 0.102$ & $2.09 \pm 0.01$ \\
5 & Total Flavonoids & $23.36 \pm 1.27$ & $50.88 \pm 2.78$ \\
\hline
\end{tabular}

$\mathrm{SD} n=3$

Table 2: Effect of percentage viable cell UV treated plant extract of Hibiscus cannabinus Linn.

\begin{tabular}{ccccc}
\hline S.NO & $\begin{array}{c}\text { Concentration } \\
(\mathrm{mg} / \mathrm{ml})\end{array}$ & Control & \multicolumn{2}{c}{$\begin{array}{c}\text { Percentage Viable Cell } \\
\text { T/C (cell control) X100 }\end{array}$} \\
\cline { 4 - 5 } & 0.3 & 1.14 & 98 & Non-UV \\
\hline 1 & 0.6 & 1.14 & 79 & 84 \\
2 & 1.2 & 1.14 & 65 & 66 \\
3 & 2.5 & 1.14 & 52 & 58 \\
4 & 5 & 1.14 & 35 & 37 \\
5 & & & & 17 \\
\hline
\end{tabular}


on the monolayer suctioned, and $100 \mathrm{hL}$ of normal and changing $\log$ concentrations of concentrate $(100-700 \mu \mathrm{g} / \mathrm{mL})$ was included and brooded for 24, 48, and $72 \mathrm{hr}$ time focuses. After the particular occasions of introduction to the concentrate, $20 \mathrm{hL}$ of $5 \mathrm{mg} / \mathrm{mL}$ MTT in PBS was added to each well and brooded for $3 \mathrm{~h}$ at $37^{\circ} \mathrm{C}$ in a $5 \% \mathrm{CO} 2$ environment. Supernatants are evacuated and $150 \mu \mathrm{L}$ of isopropanol included and the plates were tenderly shaken for $15 \mathrm{~min}$ to solubilise the formazan gems and absorbance was estimated at $560 \mathrm{~nm}$ utilizing Bio Tex ELX 800 plate peruser. In another examination, the impacts of Chromolaenaodorata alone and with mitogens (VEGF and ET-1) on colorectal malignant growth cell lines (HT29) feasibility following 24 and 48 hours exploring. ${ }^{15}$

\section{RESULTS AND DISCUSSION}

\section{Growth characteristics}

Hibiscus cannabinus Linn treated under UV-B radiation showed various growth characteristics, photosynthetic pigments and antioxidant enzymes. The irradiation caused morphological changes such as leaf curling and foliar damage. After 20 days of UV-B treatments growth characteristics such as root length, the total length of the seedlings.

In UV-B exposed plants maximum chlorophyll content were initially increased on the $3^{\text {rd }}$ day then gradually reduced and significant decrease in total chlorophyll content of plants as compared to non UV exposed plants. Protein contents were decreased compared with the control level and Proline and total flavonoids increased with increasing of level UV of radiation.

\section{Pharmacological responses}

After 72 hours MTT assay showed that extract caused a similar effect of both non UV and UV light exposed plant. Indicate no toxic elements are produce during UV light treatment.

\section{CONCLUSION}

The penetration of ultraviolet radiation varies among different plant species and may reflect their sensitivity. we found the effects of UV-B on Hibiscus cannabinus Linn showed the 15 days of UV-B treatment affected the growth parameters and photosynthetic pigments. Chlorophyll and carotenoid content were reduced thus photosynthetic pigments were destroyed by UV radiation. Significant changes found in the biochemical constituents such as proteins, total sugars and total phenols. Total sugar content decreased, but phenolic content and proteins accumulated in UV-B exposed plant.
The results indicate that both UV treated and Untreated plant extracts show cytotoxicity against the human colon cancer (HT-29) cell lines. Interestingly, the extract from UV treated plant shows much higher cytotoxicity for the same concentration when compared to extract from natural plants indicating enhancement of bioactive compounds in the UV treated plants.

\section{ACKNOWLEDGEMENT}

The authors are thankful to the Management, SRM College of Pharmacy, SRMISTfor providing necessary laboratory facilities.

\section{REFERENCES}

1. Zuk-golaszewska K, Upadhyaya MK, Golaszewski J. The effect of uv-b radiation on plant growth and development. Plant Soil Environ. 2003;49(3):135-40.

2. Gabersčik A, Jones A, Jansen M. All you wanted to know about uv radiation and plants.

3. Salama hm, Al Watban AA, Al-fughom AT. Effect of ultraviolet radiation on chlorophyll, carotenoid, protein and proline contents of some annual desert plants. Saudi J Biol Sci. 2011;18(1):79-86.

4. Teramura AH. Effects of ultraviolet-B radiation on the growth and yield of crop plants. Physiologia Plantarum. 1983;58(3):415-27.

5. Tevini M, Iwanzik W, Thoma U. Some effects of enhanced UV-B irradiation on the growth and composition of plants. Planta. 1981;153(4):388-94.

6. Ramya S, Balakrishnan V. The effect of over exposure of Ultraviolet-B radiation on the physiological characteristics of Aeschynomene aspera L. Res Plant Biol. 2013;3(3).

7. Sengul M, Yildiz H, Gungor N, Cetin B, Eser Z, Ercisli S. Total phenolic content antioxidant and antimicrobial activities of some medicinal plants. PJPS. 2009;22(1).

8. Marinova D, Ribarova F, Atanassova M. Total phenolics and total flavonoids in Bulgarian fruits and vegetables. J Univ Chem Techol Mettllury. 2005;40(3):25560 .

9. Connor AM, Luby JJ, Tong CB, Finn CE, Hancock JF. Genotypic and environmental variation in antioxidant activity, total phenolic content, and anthocyanin content among blueberry cultivars. J Am Soc Hortic Sci. 2002;127(1):89-97.

10. Yuvaraja KR, Santhiagu A, Jasemine S. Antioxidant and hepatoprotective potential of Hydnocarpus laurifolia: $A n$ in vitro and in vivo evaluation. JPBS. 2018;6(3).

11. Premanathan $\mathrm{M}$, Nokashima $\mathrm{H}$, Kathiresan $\mathrm{K}$, Rajendran N, Yamamoto N. In vitro anti human immunodeficiency virus activity of mangrove plants. Indian $\mathrm{J}$ Med Res. 1996;103:278-81.

12. Sundar Rajan T, Aanandhi VM. Phytochemical Evaluation and in vitro Activity of Ethanolic extract of Amaranthus tristis Linn. Int J Pharm Sci Res. 2017;9(9):1586

13. Gessler MC, Tanner M, Chollet J, Nkunya MH, Heinrich M. Tanzanian medicinal plants used traditionally for the treatment of malaria: In vivo antimalarial and in vitro cytotoxic activities. Phytother Res. 1995;9(7):504-8.

14. Patel S, Gheewala N, Suthar A, Shah A. In-vitro cytotoxicity activity of Solanum nigrum extract against Hela cell line and Vero cell line. Int J Pharm Pharm Sci. 2009;1(1):38-46.

15. Abdullah S, Abidin SA, Murad NA, Makpol S, Ngah WZ, Yusof YA. Ginger extract (Zingiber officinale) triggers apoptosis and G0/G1 cells arrest in HCT 116 and HT 29 colon cancer cell lines. Afr J Biochem. 2010;4(5):134-42.

\section{GRAPHICAL ABSTRACT}

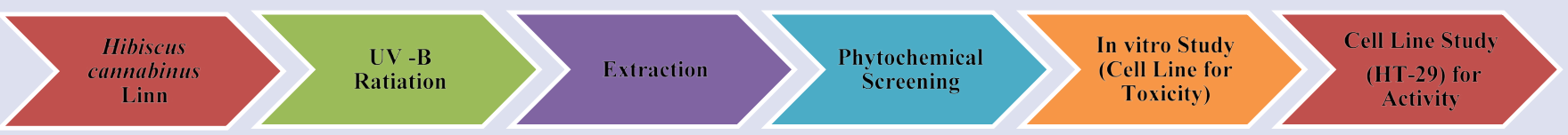




\section{ABOUT AUTHORS}

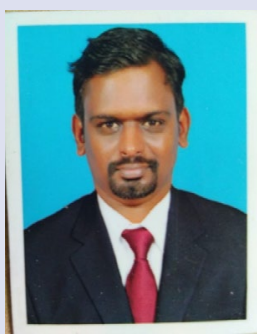

Dr.T.Sundarrajan obtained his B.Pharm degree f degree from The Tamil Nadu Dr. M.G.R. Medical University, M. Pharm. (Pharmaceutical Chemistry) from The Tamil Nadu Dr. M.G.R. Medical University and Ph.D. degree in Pharmacy from vels university Chennai. Working as Associate Professor in the Department of Pharmaceutical Chemistry in SRM College of Pharmacy. His research interests are Insilico Phytochemical Analysis with Pharmacological study of as diabetics and its Complication. He has Twenty-three research papers published in refereed International Journals to my credit. He also presented more than 30 research papers in International and National Conferences. I have been an active organizing member in 5 different conferences held at SRM College of Pharmacy.

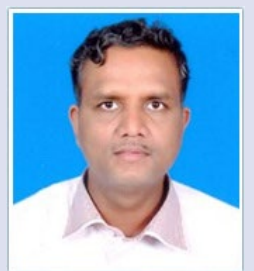

Dr.V.Velmurugan obtained his B.Pharm degree from The Tamil Nadu Dr. M.G.R. Medical University, Chennai, M. Pharm. (Pharmaceutical Chemistry) from Jadavpur University, kolkota and Ph.D. degree in Pharmacy from Periyar Maniammai University Thanjavur. He is working as Associate Professor in the Department of Pharmaceutical Chemistry in SRM College of Pharmacy. His research interests are Insilico Phytochemical Analysis with Pharmacological study of as Antiepileptic drug from natural sources. He has thirty-three research papers published in refereed International Journals to his credit. He also presented more than 40 research papers in International and National Conferences. I have been an active organizing member in 10 different conferences held at SRM College of Pharmacy.

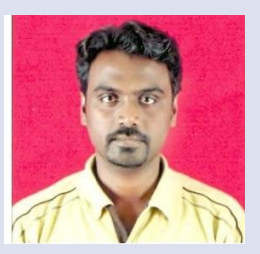

M.K.Kathiravan obtained his B. Pharm. degree from The Tamil Nadu Dr. M.G.R. Medical University, M. Pharm. (Pharmaceutical Chemistry) from Pune University and Ph.D. degree in Pharmaceutical Chemistry, from Bharati Vidyapeeth University, Pune. He was a JRF in UGC research project and SRF in ICMR research project, New Delhi. He is currently working as Professor in SRM college of Pharmacy, SRM IST, Chennai. His research interest spans in the field of synthetic organic chemistry, medicinal chemistry including the design, synthesis, and development of small organic molecules as anticancer and anti tb agents. He has more than 42 publications and one patent to his credit. He has received research grants from DST, Pune University and SRM IST.

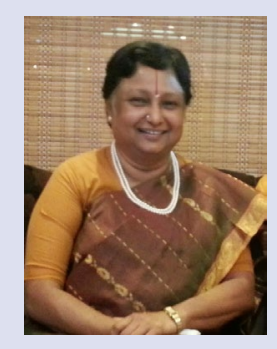

Prof.K.S.LAKSHMI done in Bachelor of Pharmacy (1986) and Master of Pharmacy (1988, through GATE) in Birla Institute of Technology, Ranchi Bihar, India. Ph.D was done in the year of 2004 in The Tamil Nadu Dr. MGR Medical University, Chennai, India. She is working as Dean, SRM College of Pharmacy, SRM Institute of Science and Technology, Chennai for the past 24 years (1996-Till date). She received the Dr.P D Sethi Annual award in the year 2011 and 2012 for best paper publication. She has more than 120 research papers published in refereed International Journals and 4 Patent to her credit.

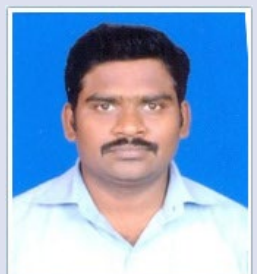

Dr.K.Manikandan born on $12^{\text {th }}$ December 1984 at Namakkal (Tamil Nadu, India), did his B. Pharm. (2006) and M. Pharm. (2009) from Department of Pharmaceutical Analysis in SRM College of Pharmacy, SRM Institute of Science and Technology, Kancheepuram, Tamil Nadu. In 2009, he joined as a Lecturer in the Department of Pharmaceutical Analysis in SRM College of Pharmacy. His research interests are development of bio analytical techniques for quantitative determination of known compounds/drugs and their impurities in biological samples. He has eighteen research papers published in refereed International Journals to his credit. He has also and presented research papers in International and National Conferences. He received the Dr.PD Sethi Annual award in the year 2011 for best paper publication. He has been an active organizing member in 12 different conferences held at SRM College of Pharmacy. He is a Life member of Pharmacy Council of India and Association for Pharmacy Teachers of India (APTI).

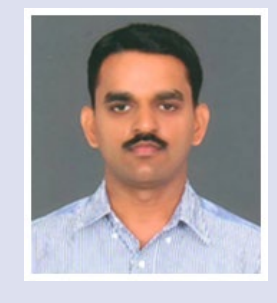

Dr M R Ganesh was done in B.Sc., (Chemistry -1996), M.Sc, (Chemistry -1998) and Ph.D (Chemistry-2004) in University of Madras, Chennai, India. He is working as Assistant Professor, Interdisciplinary School of Indian System of Medicine, SRM Institute of Science and Technology, Chennai for the past 7 years (1996Till date). He has more than 50 research papers published in refereed International Journals to his credit. He having additional experience of Post-doctoral in various country such as US and Canada.

Cite this article: Sundarrajan T, Velmurugan V, Kathiravan MK, Manikandan K, Lakshmi KS, Ganesh MR. The Effect of Ultraviolet-B Radiation Exposure on Hibiscus cannabinus Linn with its Phytochemical and Pharmacological Responses. Pharmacog J. 2019;11(6) Suppl:1540-3. 